Dept. of Parasitology,

Fac. of Medicine, Assiut University, Assiut.

\title{
SOME STUDIES ON THE EPIDEMIOLOGY OF ASCARIDIA GALLI IN ASSIUT GOVERNORATE, WITH SPECIAL REFERENCES TO ITS PATHOLOGICAL EFFECT ON EXPERIMENTALLY INFECTED MICE
}

(With 3 Tables and 4 Plates)

By R.M.A. KHALIFA; AMANY I. HAMZA; M.I.ARAFA*;
NEVEEN A. EL-NISR* and WAFAA G. MAHMOED*
*Animal Health Research Institute. Assiut Laboratory. (Received at 16/12/2006)

بعض الدراسات على وبائية الاسكارديا جالى فى محافظة اسيوط

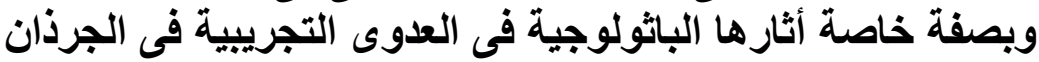

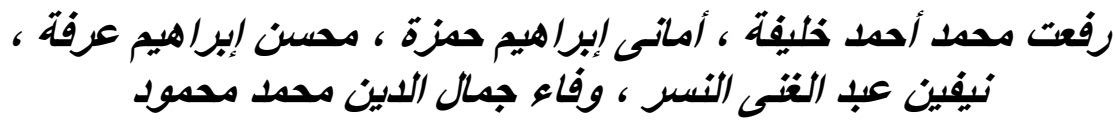

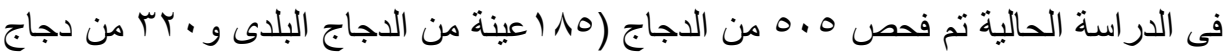

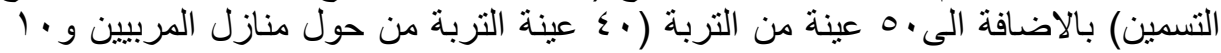

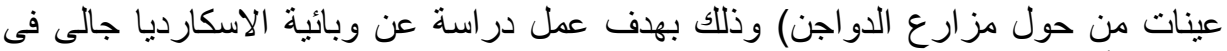

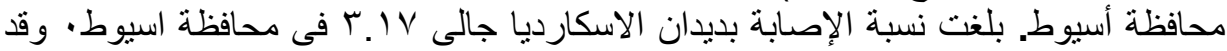

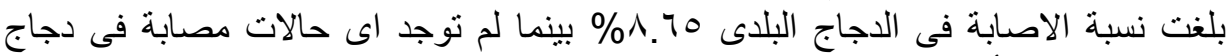

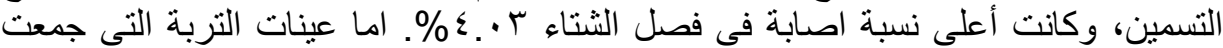

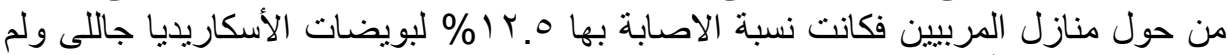

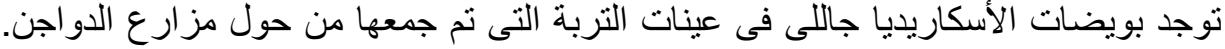

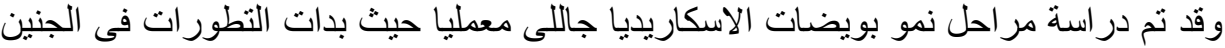

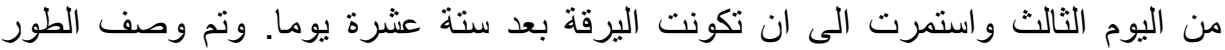

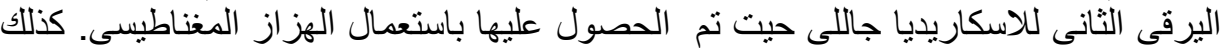

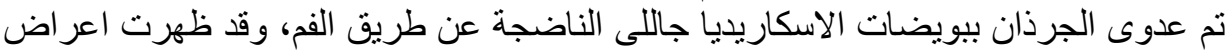

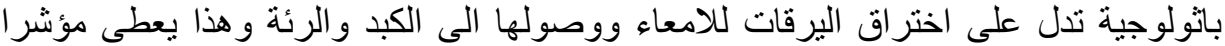

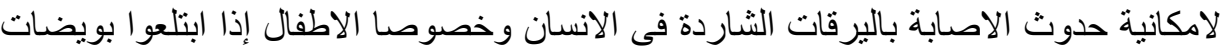

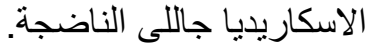


In the present study, 505 of chicken (185 native breed chickens and 320 fating breed) in addition to 50 soil samples (forty soil samples from around farmer houses and 10 from around poultry farms) were examined for epidemiological study of Ascaridia galli in Assiut Governorate. The infection rate of $A$. galli in chickens was $(3.17 \%)$ where in native breed chickens was and it was not detected in fatting breed. The highest infection rate was detected in winter season $(4.03 \%)$. The rate of positive soil samples from around farmer houses was $(12.5 \%)$ for A.galli eggs and no eggs were encountered in soil samples collected from around poultry farms. Developmental stages of A. galli eggs were studied. Embryonation of eggs started at the third day and complete embryonation with the development of larvae within egg shell occurred on the $16^{\text {th }}$ day. Second stage larvae of $A$. galli were described and microphotographed, they were obtained by using of magnetic stirrer. Experimental infection of laboratory mice with fully embryonated eggs of Ascaridia galli was done per mouth. Pathological features indicating larval invasion of the intestine, liver and lung were noticed. This indicated that $A$. galli might be transmitted to humans specially children by eating raw vegetables contaminated with soil and causing visceral larval migrans.

Key words: Ascaridia galli, native breed, fating breed.

\section{INTRODUCTION}

The parasitic nematode Ascaridia galli occurs in the small intestine of the chicken, goose, turkey, and various wild birds in most parts of the world (Kates \& Colglazier, 1970 and Andersen, 1992). A.galli has a direct life cycle, involving two principle populations: the sexually mature parasite in the gastrointestinal tract of infected bird and the infective stage larva inside a resistant egg in environment (Araujo\& Bressan, 1977). The infected birds become unthrifty, markedly emaciated, generally weak, egg production is decreased and in heavy infection intestinal obstruction may occur (Soulsby, 1982).

Extra-intestinal migration of larval ascarids of animals and birds, usually in the internal organs of an abnormal host (usually man) is known as visceral larva migrans (Cypess \& Glickman, 1976). Visceral larva migrans reported to occur due to larval invasion of Toxocara canis (Beaver, 1969), Toxocara cati (Swerczek et al., 1971), Toxocara vitulorum (Soulsby, 1983) and Toxoascaris leonina (Fukase et al., 
1987). Three cases of human visceral larva migrans were suspected by (Ito et al., 1986) to be due to ingestion of raw livers of chickens and cows (harbouring larvae of Ascaridia galli and Toxocara sp.). The clinical signs of visceral larva migrans in human are dyspnoea, cyanosis, hyperleukocytosis, eosinophilia, hepatomegaly and even death specially when they reach the brain (Beaver, 1969 and Schmidt and Roberts, 1989).

The present work was designed to study the epidemiological status affecting the prevalence of A. galli in Assiut Governorate, in addition to a trial to infect laboratory mice with larvated eggs of $A$. galli for studying its pathological effect in different internal organs.

\section{MATERIALS and METHODS}

\section{I- Collection of samples:}

In this study 185 native breed chickens (6-18 month old) and 320 fatting breed chicken (30-45 days old) in addition to 50 soil samples (10 from around poultry farms and 40 samples from around farmer houses) were collected from different localities of Assiut Governorate (Assiut city, Mankabad and Dronka villages).

\section{II- Post-mortum examination of chickens:}

Small intestine of sacrificed chickens were opened and examined for detection of adult worms of A. galli.

\section{III- Examination of soil samples:}

Soil samples were examined for the presence of A. galli eggs by the centrifugation floatation technique using saturated sodium chloride solution (Quinn et al., 1980).

\section{VI- Collection and cultivation of $A$. galli eggs:}

Female worms of $A$. galli were collected from the intestine of infected chicken, washed by distilled water and kept in physiological saline.

Eggs of A. galli were collected from the uterine pore by pressing these organs gently with a blunt object to squeeze the eggs out (Annen et al., 1975 and Stevens \& Jacobs, 1977).

They were suspended in $1 \%$ formal-saline and placed in petridishes at depth of $0.5 \mathrm{~cm}$ physiological saline. The suspension was then left at room temperature ranging between $22-25{ }^{\circ} \mathrm{C}$ under continuous aeration. Observation for development was done by binocular microscope (Oshima, 1961 and Bisseru \& Woodruff, 1968).

Second stage larvae of $A$. galli were obtained by using of magnetic stirrer after incubation of larvated eggs with $2 \%$ sodium 
hypochlorite for 24 hours (Annen et al., 1975), they were described and microphotographed.

\section{V- Experimental work:}

20 parasite free laboratory albino mice were used (15 were test animals and 5 were control animals).

\section{1- Experimental infection of laboratory mice:}

The diluted A. galli larvated eggs were shaken vigorously and aspirated immediately with a tuberculin syringe containing a special blunt curved needle.

The needle was introduced carefully in the oral cavity of mouse and all the contents of the syringe emptied slowly.

The inoculated dose (1500 larvated eggs) was given to each animal on full stomach (Abou-El-Naga 1990).

Three experimentally infected mice and one control were sacrified according to the following schedule that was reported by Abd El-Gaffar et al., (1999):

- 48 hrs, 72 hrs, 10 days, 15 days, 20 days after infection. Macroscopic and microscopic examination of the intestine, liver, lung, heart, kidney, eye, spleen, and brain of each sacrified animals were done and pathological changes were observed.

\section{2- Histopathologicl studies:}

Specimens from different organs (intestine, liver, lung, brain and kidney) were fixed in $10 \%$ formalin and sections were stained by Ehrlich's Haematoxylin and Eosin, according to Culling (1957) and examined histopathologically.

\section{RESULTS}

\section{Epidemiological studies:}

Post-mortum examination of 505 chickens revealed that the infection rate of $A$. galli was $(3.17 \%)$, where their adult worm was detected in (16) of examined chickens. The infection rate in native breed was $8.65 \%$ while fating breed was free from A. galli infection (Table1).

Table 1: Prevalence of A. galli in chickens in Assiut Governorate.

\begin{tabular}{|c|c|c|c|}
\hline & $\begin{array}{c}\text { Native } \\
\text { Breed }\end{array}$ & $\begin{array}{c}\text { Fating } \\
\text { Breed }\end{array}$ & Total \\
\hline Ex. Animal & 185 & 320 & 505 \\
\hline Inf. Animal & 16 & 0 & 16 \\
\hline$\%$ & 8.65 & 0 & 3.17 \\
\hline
\end{tabular}

Concerning seasonal variations, the highest infection rate was detected in winter $(4.03 \%)$ followed by autumn and spring $(3.9 \%) \&(3.85 \%)$ 
respectively while the lowest infection rate was detected in summer season $(0.8 \%)$ (Table2).

Table 2: Seasonal variations of $A$. galli of chickens in Assiut Governorate.

\begin{tabular}{|c|c|c|c|c|c|c|c|c|c|c|c|c|}
\hline & \multicolumn{3}{|c|}{ Winter } & \multicolumn{3}{c|}{ Spring } & \multicolumn{3}{c|}{ Summer } & \multicolumn{3}{c|}{ Autumn } \\
\cline { 2 - 14 } & $\begin{array}{c}\text { Native } \\
\text { Breed }\end{array}$ & $\begin{array}{c}\text { Fating } \\
\text { Breed }\end{array}$ & Total & $\begin{array}{c}\text { Native } \\
\text { Bred }\end{array}$ & $\begin{array}{c}\text { Fating } \\
\text { Breed }\end{array}$ & Total & $\begin{array}{c}\text { Native } \\
\text { Breed }\end{array}$ & $\begin{array}{c}\text { Fating } \\
\text { Breed }\end{array}$ & Total & $\begin{array}{c}\text { Native } \\
\text { Breed }\end{array}$ & $\begin{array}{c}\text { Fating } \\
\text { Breed }\end{array}$ & Total \\
\hline $\begin{array}{c}\text { Ex. } \\
\text { Animal }\end{array}$ & 44 & 80 & 124 & 50 & 80 & 130 & 43 & 80 & 123 & 48 & 80 & 128 \\
\hline $\begin{array}{c}\text { Inf. } \\
\text { Animal }\end{array}$ & 5 & 0 & 5 & 5 & 0 & 5 & 1 & 0 & 1 & 5 & 0 & 5 \\
\hline$\%$ & 11.63 & 0 & 4.03 & 10.0 & 0 & 3.85 & 2.32 & 0 & 0.8 & 10.42 & 0 & 3.9 \\
\hline
\end{tabular}

The result of examination of soil samples for A.galli eggs was $(10 \%)$, it was detected in $5(12.5 \%)$ of examined soil samples around the farmer houses while samples around poultry farms were negative for A.galli eggs (Table 3).

Table 3: Incidence of A.galli eggs in soil samples.

\begin{tabular}{|c|c|c|c|}
\hline Items & $\begin{array}{c}\text { Samples around } \\
\text { poultry farm } \\
(\mathrm{n} .=10)\end{array}$ & $\begin{array}{c}\text { Samples around } \\
\text { farmer } \\
\text { houses(n.=40) }\end{array}$ & Total (n.=50) \\
\hline $\begin{array}{c}\text { No. of positive } \\
\text { samples }\end{array}$ & 0 & 5 & 5 \\
\hline$\%$ & 0 & 12.5 & 10 \\
\hline
\end{tabular}

\section{Morphological studies:}

Development of $A$. galli eggs:

Embryonation of $A$. galli eggs started to occur on the third day, where 2- cell stage embryos were noticed, on the seventh day post incubation, 4- cell stage embryos could be seen, on the eleventh day, 8cell stage embryos were developed and on the fourteenth day morula stage appeared. Complete embryonation with the development of larvae inside the egg shells occurred on the sixteenth day (plate I, 1,2, 3\& 4).

\section{Ascaridia galli $2^{\text {nd }}$ stage larvae:}

Second stage larvae of $A$. galli were obtained by using of magnetic stirrer, they have sluggish movements and after four hours they started to relax, then internal organs could be seen more distinctly. Hatched larvae are stout provided with rounded anterior end and pointed posterior end. The posterior part of their body was filled with abundant 
dark granules for which their intestinal cells were indistinct. These larvae measured 220-260 $\mu$ (mean 237.5 $\mu$ ) in length, 20.2- 26.7 $\mu$ (mean $22.9 \mu$ ) in width, their esophagus was $80-90 \mu$ (mean $87.5 \mu$ ), and their tail was $28-33 \mu$ (mean $30.5 \mu$ ) (plate I, 5,6,7,\& 8).

\section{2- Histopathology:}

\section{Intestine:}

Histopathological examination of H\&E stained sections, 3 days post-infection, showed faint-pink mucinous exudate on the mucosal surface, increased number of goblet cells and increased mononuclear inflammatory reaction in the lamina propria, mainly eosinophils (plate II, 1,2).

The intensity of inflammatory cellular reaction increased with the time of infection. 10-20 days post- infection, mononuclear inflammatory cells predominate in the lamina propria with few eosinophils (plate II,3).

\section{Liver:}

Histopathological changes in the liver are also dependent on the period of infection. From 2-3 days post-infection congestion of both central and portal veins with mild to sever necrobiotic changes in some hepatocytes could be seen (plate II, 4). Sections examined 10 days postinfection showed subcapsular mononuclear cellular infiltrations (plate III, 1), in this period the hepatocytes also appeared swollen with vacuolar and granular cytoplasm (plate III, 2). Moreover 15 and 20 days post- infection, there was focal mononuclear inflammatory cellular reaction (plate III, 3), and the portal vain was dilated and congested (plate III, 4).

\section{Lungs:}

Lungs were the most affected organs as a result of Ascarida galli infection. 2-3 days post- infection, lungs show alveolar emphysema (plate VI, 1). Degeneration of the bronchial epithelium and proliferation of peribronchial lymphatic tissue was prominant in this period (plate IV, 2) 10 days post- infection, the previous changes were pronounced, there were mononuclear cellular infiltration in the wall of alveoli including eosinophil and lymphocyte also there was severe alveolar haemorrhage, and alveolar emphysema with rupture of the alveolar wall (plate IV, 3). The bronchial arteriol show sever degeneration in its epithelium with some time thrombus formation, their was also perevascular mononuclear cell proliferation mainly lymphocyt and macrophage cell (plate IV, 4). Animals after 15 and 20 days post infection showed the same lesions. 


\section{LEGEND OF PLATES}

\section{Plate I}

1: A. galli egg containing two-cell stage embryo (X 132).

2: A. galli egg containing four cell stage embryo (X 132).

3: A. galli egg containing eight cell stage embryo (X 132).

4: A. galli egg contains fully developed larva (X 132).

5: A. galli hatching egg, stained with iodine (X 66).

6: A. galli $2^{\text {nd }}$ stage larva four hours after hatching (X 66).

7: Anterior end of A. galli $2^{\text {nd }}$ stage larva (X 132).

8: Posterior end of A. galli $2^{\text {nd }}$ stage larva (X 132).

\section{Plate II}

1: Intestine showing inflammatory cellular reaction, mainly eosinophils, in the lamina propria with increased number of goblet cell (3 days post- infection, H\&EX20).

2: Higher magnification of the previous picture (3 days post infection, $\mathrm{H} \& \mathrm{EX} 40)$

3: Intestine showing mononuclear cellular infiltration with few eosinophils in the lamina propria (10 days post- infection, H\&EX20).

4: Liver showing severe necrobiotc changes in the hepatocytes (3 days post- infection, H\&EX20).

\section{Plate III}

1: Liver showing subcapsular mononuclear cellular infiltration with necrobiotic changes of hepatocytes (10 days post- infection, H\&EX20).

2: Liver showing hepatic degeneration, hepatocytes appeared swollen with granular cytoplasm ( 15 days post- infection, H\&E X 20).

3: Liver showing focal mononuclear cellular infiltration (15 days postinfection, H\&E X 20).

4: Liver showing dilatation and congestion of the portal vein in the portal area (20 days post- infection, H\&E X 20).

\section{Plate IV}

1: Lung showing alveolar emphysema. Some alveoli appeared ruptured and opened with each others (3 days post- infection, H\&E X 20.

2: Lung showing proliferation of the per-bronchial lymphatic tissue ( 3 days post- infection, $\mathrm{H} \& \mathrm{E}$ X20).

3: Lung showing alveolar haemorrhage (10 days post- infection, H\&EX20). 
4: Lung showing bronchial artery with degenerated wall with thrombus formation and perivascular mononuclear cell proliferation mainly lymphocyte (10 days post- infection, H\&E X 40). 
Assiut Vet. Med. J. Vol. 53 No. 112 January 2007 
Assiut Vet. Med. J. Vol. 53 No. 112 January 2007 


\section{DISCUSSION}

Ascaridia galli is one of the most common enteric parasites of chickens and their prevalence depend on the age, breed and nutritional 
state of the birds in addition to the sanitary management of the farms (Matta, 1981).

In the present study, the infection rate of $A$. galli was $3.17 \%$ in examined chicken, where in native breeds chickens was $(8.65 \%)$ and it was not detected in fating breed. This result is considered lower than that recoded in Egypt previously by: El-Azzazy (1979), Abd-El-Salam (1981) and Sayed (1996) (75.9 \%, 50.66\% and 20.83\% respectively). These gradually decreasing of the incidence of A. galli in chiken might be related to decrease of total number of native breeds of chickens as a result of spreading of fatting breeds in addition to periodical using of antihelmintic drugs.

Absence of infection in fating breeds might be related to this chickens were slaughtered at young age (40-45 days old) In addition to improvement of the sanitary conditions used in the farms of these breeds.

Concerning seasonal variations in the present work, the highest infection rate was detected in winter $(4.03 \%)$ while the lowest one was detected in summer season $(0.8 \%)$. This may be due to the hot weather of Upper Egypt in summer season. Soulsby (1982) mentioned that eggs of $A$. galli can remain viable for long period in shaded places and rapidly killed by dry, hot weather even when they are 6 inch deep under the soil exposed to sunlight.

Results in Table (3) showed that no eggs of A. galli were found in soil samples collected from around poultry farms as compared with samples around farmer houses $(12.5 \%)$. This may be due to periodically changing of the litter and using of disinfectant especially prior to introdution of a new hatch of chickens to the farm in addition to using of antihelmintics as a prophylaxis.

In the present study, the development of Ascaridia galli eggs was described-for the first time- in details. The steps of development were described at certain intervals. Embryonation started on the third day post incubation and complete maturation with appearance of larvae inside eggs started on the $16^{\text {th }}$ day. Also, during the present study artificial hatching of eggs was done and the second stage larvae of A. galli were described. El-Nazer et al., (2004) developed the eggs but stated that complete maturation occurred after 32 days but they did not mention the details of the stages of development. Rapid development in the present study may be due to better environmental conditions.

Pathological changes started to appear within few days (3-4 days) and were evident in the intestine, liver and lung of experimentally 
infected mice. Our result in the intestine indicated acute catarrhal enteritis at first 3 days post infection and chronic catarrhal enteritis till end of the experiment at 20 day post infection. This is consistent with results obtained by Willoughby et al. (1995) as they found that Ascaridia dissimilis larval migration in turkey lead to eosinophilic and lymphocytes enteritis, they added also that the intestinal pathology of this nature could be expected to affect normal enteric function.

Although we did not find the larva in the liver its lesions "the degenerative changes associated with cellular infiltration under the liver capsule and the reaction in the portal tract" may indicate the mechanical damage caused by the migration of the larva. This result agrees with Abd El-Ghaffar et al. (1999) who found that the tissue alterations in experimentally infected mice with Parascaris equorum were due to mechanical damage from larval migration which lead to necrobiotic changes in the hepatocytes and wall of the hepatic blood vessels. Also Elnazer et al. (2004) found that Ascaridia galli larval migration in the liver cause mononuclear inflammatory cells "lymphocytes, histocytes, and eosinophils "infiltration of the liver parenchyma" lobules \&portal areas".

The lung tissue was the most affected tissue as it is the only organ that showed sever haemorrhage with leucocytic response in which the eosinophilia was predominating. Our work also indicated mononuclear cells infiltrating into the alveolar wall which agrees with El-Sherry and Tawfik (1974) who found the larva of Neoascaris vitulorum in the alveoli and bronchi of lung of Gunia Pigs and found the exudative leucocytic respons. Elnazer et al. (2004) found that Ascaridia galli larval migration in lung causes interalveolar septal infiltration with mononuclear cellular infiltration which was pronounced in the $4^{\text {th }}$ week post infection and gradually decreased in the succeeding weeks. These results also were showed by Hungerford (1950), Hanns (1985), Urquhart et al. (1987), and Abd El-Ghaffar et al. (1999) who found that the Parascaris equorum larval migration in the lung caused extensive alveolar and perivascular hemorrhage, degeneration in the bronchial epithelium and vessel walls in addition to the picture of parasitic bronchopneumonia.

\section{REFERENCES}

Abd El-Gaffar, S.Kh.; Khalifa, R.M. and Arafa, M.I. (1999): Pathological studies on the experimental infection of mice with 
Parascaris equorum. Egypt J. Comp. Path. and Clinic. Path., 12: 76-87.

Abd El-Salam, F.A. (1981): Studies on the life cycles of some helminthes of poultry in Assiut Governorate. Ph.D. Thesis, Fac. Vet. Med., Assiut University.

Abou-El-Naga, F.I. (1990): An attempt to induce immunity against Toxocara canis infection in albino mice. M.D. Thesis in Parasitology, Faculty of Medicine, Alexandria University

Andersen, R.C. (1992): Nematode parasites of vertebrates. Their development and transmission $\mathrm{CAB}$ International. Cambridge University Press. Cambridge

Annen, J.M.; Eckert, J. and Hess, M. (1975): Eine einfach method Zur gewinnung von Toxocara canis. Antigen fur indirekte immunofluorescenz-technik. Acta Tropica, 32: 37-47.

Araujo, P.B. and Bressan, (1977): Consideration sur la aeuxieme mue des larves d Ascaridia galli. Ann parasitol., 5 :531-537.

Beaver, P.C. (1969): The nature of visceral larva migrans. J. Parasitol., 55:3-12.

Bisseru, B. and Woodruff, C. (1968): Studies on the liver, lung, brain and blood of experimental animals infected with Toxocara canis. J. Helminthol., 43: 267-272.

Culling, C.F.A. (1957): Handbook of Histopathological Technique, $1^{\text {st }}$ ed. London: Butter Worth Co. Ltd., 304.

Cypess, R.H. and Glickman, L.T. (1976): Viseral larva migrans, a significant zoonosis. Med. Vet. Practic., 57: 462-464.

El-Azzazy, O.M. (1979): Studies on the helminth parasites of poultry in Sharkia Governorate. M.V.Sc. Thesis, Fac. Vet. Med. Zagazig University.

El-Nazer, M.; El-Hady, H.A.; Abu-Dife, E.E.; Ammar, K.N. and Hussein, M.R. (2004): Larva migrans in mice following infection with embryonated eggs of Ascaridia galli: an animal model. $11^{\text {th }}$ Sc. Cong., Fac. Vet. Med., Assiut Univesity., Egypt, PP. 383-391.

El-Sherry, M.I. and Tawfik, M.A. (1974): The pathology of experimental infestation of Neoascaris vitulorum in guinea pigs. Assiut Vet. Med. J. (1). 1-12.

Fukase, T.; Ohuchi, Y.; Saegus, M.; Chinome, S.; Itaga, H.; Highuchi, S.; Ogata, M. and Suzuki, T. (1987): Toxoasaris leonina infection of Japanes -bred domestic cats and antihelmintic 
medication with milbemycin. Japan. Vet. Med. Ass., 40 (8): 574-576.

Hanns, J.W. (1985): Equine disease. Text book for students and practitioners. Verlag, Paul Parey, Berlin and Hamburg.

Hungerford, T.G. (1950): Disease of livestock, Mcgrocr Hil. Book company Sydney, 1435-1456.

Ito, K.; Sakai, K.; Okajima, T.; Ouchi, K.; Funakoshi, A.; Nishimura, J.; Ibayash, H. and Tsuji, M. (1986): Three cases of visceral larva migrans due to ingestion of raw chicken or cow liver. Nihon Naikagaku Zassi, 75: 759-766.

Kates, K.C. and Colglazier, M.L. (1970): Differential morphology of adult Ascaridia galli (Schrank 1788) and Ascaridia dissimilis (Perez Vigueras1931). Proc. Helminthol. Soc Wash. 37: 80 -84.

Matta, S.C. (1981): Effect of Ascaridia galli infection on the egg production in poultry. Indian J. Poult. 15:1-4.

Oshima, T. (1961): Standarization of techniques for infecting mice with T. canis and observation of the normal migration routes of the larva. J. Parasitol., 47: 652.

Quinn, R.; Smith, H.V.; Bruce, R.G. and Girdwood, R.W.A. (1980): Studies on the incidence of Toxocara and Toxoascaris spp. Ova in the enviroment.1.A comparison of floatation procedures for recovering Toxocara spp. ova from soil. J. Hyg. Comp., 84: 83-89.

Sayed, G.M. (1996): Some parasitological and immunological studies on parasites of chickens. M.V.Sc. Thesis, Fac. Vet. Med. Assiut University.

Schmidt, G.D. and Roberts, L.S. (1989): Foundations of Parasitology $4^{\text {th }}$ ed. Times Mirrior / Mosby College publishing. Toronto.

Soulsby, E.J.L. (1982): Helminthes, Arthropods and Protozoa of domestic animals. $7^{\text {th }}$ Ed., English Book Society and Bailliere Tindall, London, U.K.

Soulsby, E.J.L. (1983): Zoonoses in practice, Toxocariasis. Brit. Vet. J., 139: 471-475.

Stevens, P. and Jacobs, D.E. (1977): Toxocara infection in pigs. The use of indirect fluorescent antibody tests and an in vitro larval precipitate test for detecting specific antibodies. J. Helminthol., 51: 142.

Swerczek, T.W.; Nielsent, S.W. and Helmboldt, C.F. (1971): Transmammary passage of Toxocara cati in the cat. Am. J. Vet. Res., 32: 89-92. 
Urquhart, G.M; Armour, J.A.; Duncan, J.L; Dunn, A.M. and Jennings, F.W. (1987): Veterinary Parasitology. English language Book Society. Longman, 285pp.

Willoughby, D.H.; Bickford, A.A. and Charlton, B.R. (1995): Ascaridia dissimilis larval migration associated with enteritis and low market weight in meat of turkeys. Avi. Dis. 39: 837-843. 